\title{
エポキシ樹脂系ひび割れ注入材の 低温環境における注入性能の評価
}

\author{
内藤 勲 1 - 横田 弘 2 \\ 1 正会員 土木研究所寒地土木研究所 而寒材料チーム 主任研究員（†062-8602 札幌市豊平区平岸 1-3） \\ E-mail: ih-naitoh@ceri.go.jp \\ 2 フェロー会員 北海道大学大学院教授 工学研究院（干060-8628 札幌市北区北 13 西 8) \\ E-mail: yokota@eng.hokudai.ac.jp
}

\begin{abstract}
本論文は，低温環境におけるエポキシ樹脂系ひび割れ注入材の注入充填性を定量的に評価するため, 低 温での注入材の粘度変化と温度変化の計測およびコンクリート供試体による注入実験を行い, 既往の研究 で提案された注入面積速度を用いて低温時の注入性能と施工性を検討した結果を考察するものである. 注 入材粘度の経時変化等の計測および注入充填性試験を行った結果, 低温や少量では注入材の反応による発 熱がほとんど発生しないため, 注入性能はひび割れ内部の環境温度に依存することを明らかした。また， 注入面積速度式に, 環境温度 $5^{\circ} \mathrm{C}$ 以下の低温域の場合の補正係数を導入すると, この関係式から低温環境 におけるエポキシ樹脂系ひび割れ注入材の注入充填性の定量的な評価が可能であることを確認した.
\end{abstract}

Key Words : cold environment, epoxy resin, injection areal rate, injection performance

\section{1. はじめに}

コンクリートに発生したひび割れは，水や塩分等の劣 化因子の浸入経路となり，コンクリートが劣化しやすい 環境にあると劣化の進行を早めることが知られている 1 . ひび割れ注入工法は古くからコンクリート構造物に用い られている補修対策の一つであり，ひび割れからの劣化 の進行を抑える目的で，ひび割れ内部に樹脂系材料やセ メント系材料を注入してひび割れを閉塞させる補修方法 である.この補修工法は注入材がひび割れ内部に十分に 充填されることが前提となる ${ }^{2)}$. ひび割れ注入工法はコ ンクリートのひび割れに直接対策を施す工法であり，乾 燥収縮ひび割れや温度応力ひび割れ等の初期欠陥, 凍害 やアルカリシリカ反応による劣化によって生じるひび割 れ等, 劣化や損傷がさほど大きくないコンクリート表面 のひび割れ幅がおおむね $1 \mathrm{~mm}$ 以下のコンクリートに適 用される 3). しかしながら，実際のひび割れ注入工事に おいて，低温環境下では注入箇所から早期に漏水やエフ ロレッセンス等の析出物が再発する事例が多く報告され ている（図-1）。この原因として著者らは過去の調査・ 実験において，積雪寒冷地のひび割れ注入工事で注入材 の充塡率が低いケースが多くあること（図-2） 4), 5)，また， 室内実験において, 供試体のコンクリート温度が低温と なる状況では注入材の未充填が生じる場合があることの
を確認している. しかし，このような不具合を是正する 適切な施工方法や新たな対策方法等は未だ確立されてい ない.

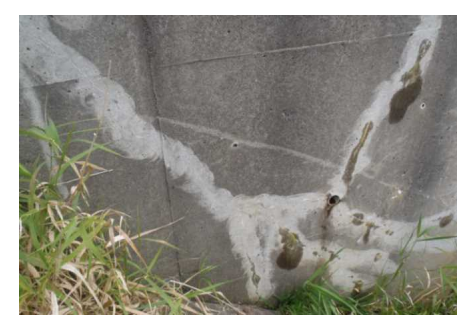

図-1 ひび割れ注入による補修後の不具合再発事例

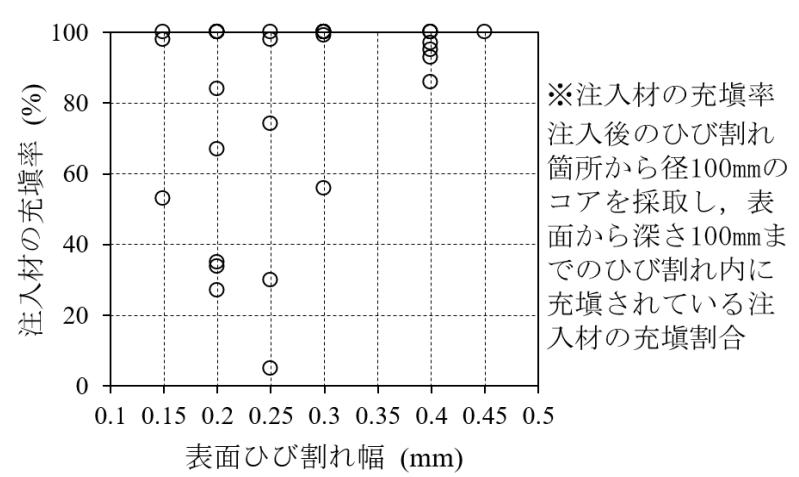

図-2 ひび割れ注入における表面ひび割れ幅と注入材の充 填率の関係 ${ }^{4), 5}$ 
ひび割れ注入工法におけるひび割れ注入材の品質規格 は，1985 年度 (昭和 60 年度) 〜 1987 年度 (昭和 62 年 度）の建設省総合技術開発プロジェクト「コンクリート の耐久性向上技術の開発」（以下，耐久性総プロ）にお いて, 劣化したコンクリート構造物の補修技術に関する 研究成果によって主に $20^{\circ} \mathrm{C}$ の環境における性状を基本 として規格化されている。しかし，低温環境としては $5^{\circ} \mathrm{C}$ における実験結果を基にエポキシ樹脂系ひび割れ注 入材の粘度を「4000 cps (4000 mPa・s) 以下であることが 望ましい」と記述されているのみで，規格值や留意点は 明記されていない7). また，日本コンクリート工学会の コンクリートのひび割れ調査, 補修・補強指針において も注入材の品質規格は耐久性総プロが参照されている ${ }^{8)}$ この耐久性総プロにおける補修技術指針は塩害およびア ルカリシリカ反応による劣化を受けたコンクリート構造 物へ適用されるが，その後 30 年ほど，国土交通省とし て土木コンクリート構造物の補修材料・工法について整 理された技術資料等の作成は行われていない.

また，寒冷地域における実際のひび割れ注入作業では， 一般的な施工環境の最低温度である $5^{\circ} \mathrm{C}$ 前後での施工も 通常実施されており，防寒費が計上されない 10 月では $5^{\circ} \mathrm{C}$ 以下であっても防寒囲いを使用しない事例がみられ る.このような低温環境で注入作業を行った場合, エポ キシ樹脂系注入材の粘度は高くなって流動性が悪くなる ため, 部材厚の大きいコンクリート構造物のひび割れに は奥まで注入材が充继されない可能性がある.さらに, 注入時間についても，耐久性総プロでは施工性も考慮さ れており, 注入の翌日に注入器を撤去する手順があるこ とから，低温環境では注入材がまだ硬化していない状態 でも注入工事が完了する事例もある.

このような背景から本研究では，ひび割れ注入工法の 注入性と充填性（以下，注入充填性）を向上させる方策 および低温環境におけるひび割れ注入材の性能の規格化 を目標とした。 まず，使用頻度が多いエポキシ樹脂系ひ び割れ注入材に焦点を当て，室内実験において異なる温 度環境におけるエポキシ樹脂系ひび割れ注入材の粘度変 化と温度変化の把握を行った。 さらに，異なる温度環境 でコンクリート供試体への注入実験を行い，既往の研究 によって提案された注入面積速度式を用いて注入性能を 検証した. 最後に, エポキシ樹脂系ひび割れ注入材の低 温環境における注入充塡性を評価した。本論文はこれら の結果について述べる.

\section{2. ひび割れ注入工法の品質管理}

\section{(1) ひび割れ注入工法の問題点と既往の研究}

ひび割れ注入工法の品質管理における最大の問題点と
して，ひび割れ内部に充填されたひび割れ注入材の充填 状況を容易に確認する手段がないことがあげられる。ひ び割れ注入工法はひび割れ内部に直接対策を施すことか ら，断面修復工法や表面被覆工法のように補修後に補修 材や補修箇所を簡単に目視できる状態になく，補修後の 品質確認と充填不良への対応は非常に困難である. 注入 状態を確認する方法としてコア削孔による確認方法があ るが，規模の大きい土木コンクリート構造物では，対象 ひび割れの大きさや深さ，位置によって確実に注入状態 を確認できないケースも出てくる. 著者らの過去の実構 造物における調査結果において，ひび割れは内部で屈曲 していることが多く, 径 $100 \mathrm{~mm}$ のコア削孔では深さ約 $200 \mathrm{~mm}$ 程度が確認可能な深さの限界であり定量的に注 入状態が把握可能な深さは $100 \mathrm{~mm}$ 程度であることを提 案している9). 注入確認を行った既往研究では, 深町ら の内視鏡力メラによる注入確認の研究 10や山口らの超音

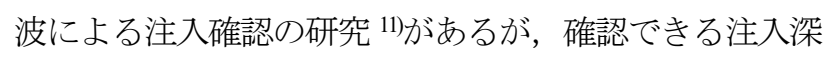
さは $100 \mathrm{~mm}$ から深くても $300 \mathrm{~mm}$ 程度までであり, 部 材厚が大きいコンクリート構造物では奥まで確認できな い.このことから，ひび割れ注入工法の品質管理は，従 来，表面ひび割れ幅とひび割れの規模によって粘性や流 動性，可使時間等が異なるひび割れ注入材を適用し，必 要注入量を管理することでひび割れ内部に確実にひび割 れ注入材が充填される, といらみなし規定が用いられて きた.しかし，これらのひび割れ注入材の選定方法や注 入条件もしくは注入時の留意点について整理されている 技術資料はなく，既述のようにひび割れ注入材の未充填 が原因と思われる注入後の漏水や析出物による再劣化が 生じている事例も多く散見される.これらの不具合はひ び割れの状態に応じた適切な施工等が行われなかった可 能性がある。

このような問題等を解決すべく, ひび割れ注入工法の 注入性の評価を試みた既往の研究がいくつかある. 上村 らはひび割れ幅と粘度と注入圧の関係から注入時の面積 速度式や注入速度式を提案している ${ }^{12)}$. この注入面積速 度の関係式を用いて, 瀬野・魚本はひび割れ内面の粗さ をフラクタル次元で定量的に表して注入時間と注入量の 予測を ${ }^{13)}$ ，西脇らはセメント系補修剂の浸透距離の予測 を ${ }^{14)}$ ，毛利・大久保は可視化試験体において，ひび割れ 注入材の粘性とひび割れ幅の影響による広がりと垂れに ついての評価を ${ }^{15}$ 行っている. しかしながら, これら既 往の研究は $20 \sim 23^{\circ} \mathrm{C}$ の温度環境における実験結果であ り，低温環境におけるひび割れ注入材の初期粘度や硬化 反応過程における粘度の変化は検討されていない.

\section{（2）エポキシ樹脂系ひび割れ注入材の硬化前の性能}

エポキシ樹脂系ひび割れ注入材の硬化前の性能の一つ である可使時間の算定方法について記述する. エポキシ 


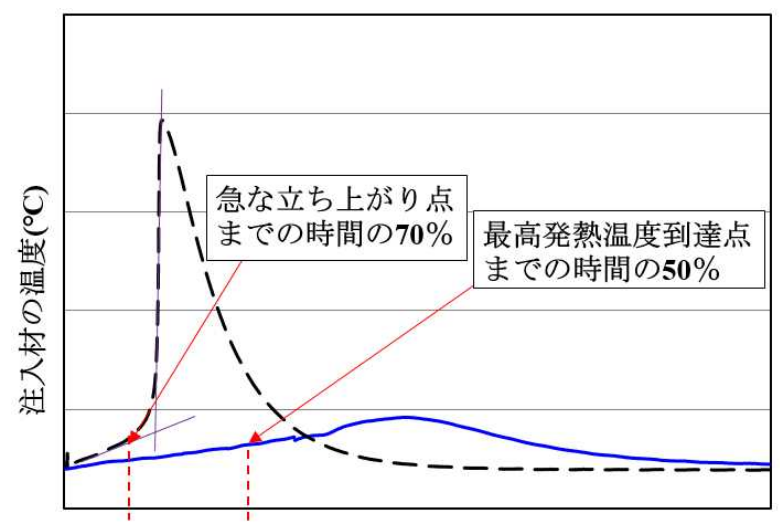

経過時間 (min)

図-3 温度上昇法による可使時間の算定例

樹脂系ひび割れ注入材はそのほとんどが 2 成分の反応硬 化型であり，これらを含めた接着剤系のエポキシ樹脂の 可使時間の多くは温度上昇法によって算定されている. この温度上昇法は, 硬化反応で発熱するエポキシ樹脂の 温度変化から可使時間を求める方法である. 可使時間の 算定方法は， $23 \pm 2{ }^{\circ} \mathrm{C}$ の温度環境において，耐久性総プ ロでは攪汼から最高硬化発熱温度に到達するまでの時間

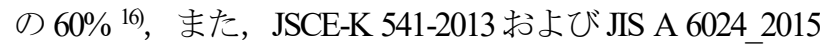
では攪拌から硬化発熱温度が急激に上昇する立ち上がり 点までの時間の $70 \%$ ，もしくは急激な立ち上がり点の判 別が困難な場合には攪拌から最高硬化発熱温度に到達す るまでの時間の $50 \%{ }^{17)}$ と規定されている（図-3）。現在， 一般的に使用されているエポキシ樹脂系ひび割れ注入材

（以下，注入材）は JSCE-K 541-2013 および JIS A 6024_2015 に基づく製品が多く，この規定に基づいて算 定された可使時間は環境温度 $23 \pm 2^{\circ} \mathrm{C}$ における值である しかし，一般に注入材は低温では粘性が高くなり可使時 間や硬化時間は長くなる性質を有する。したがって，寒 冷地において $5^{\circ} \mathrm{C}$ 前後の低温環境でも施工している実際 の工事現場では可使時間や注入充填性が異なると考えら れるが，低温環境における注入材の粘性や可使時間に明 確な規定はない.

\section{3. エポキシ樹脂系ひび割れ注入材の注入性能}

ひび割れ注入工法において，注入するひび割れ幅によ って注入のしやすさは変化する，すなわち，ひび割れ幅 が狭いほど注入しにくくなる等の施工性の特徴が一般的 に知られている。このような注入性能は，ひび割れ幅と 注入面積速度を関係づける以下の式 12)によって説明され る.

$$
S_{v}=\alpha w^{2} p / \mu
$$

ここに, $S_{v}$ : 注入面積速度 $\left(\mathrm{cm}^{2} / \mathrm{sec}\right), \alpha$ : 補正係数, $w:$ ひび割れ幅 $(\mathrm{cm}), p$ : 注入圧力 $(\mathrm{Pa}), \mu$ : エポキ
シ樹脂系注入材の粘度 $(\mathrm{Pa} \cdot \mathrm{sec})$ である.

上村らは, 式(1)により, 注入材の粘度, 注入圧力と ひび割れ幅によってひび割れ内部に流入する注入材の注 入面積速度は支配されるとしている. この注入面積速度 は，注入材をニュートン流体とした場合に，ナビエ・ス トークスの運動方程式から注入圧とひび割れ幅の二乗に 比例するとしている.さらに瀬野らの研究においては, これにひび割れ面の粗さを考慮し, 粗くなるほど注入速 度は遅くなることを明らかにしている ${ }^{13)}$.

一方，注入施工時の環境温度が低いと注入材は硬くな って流動性が悪くなり注入しにくくなることも注入材の 性能として知られている. しかし，低温時の注入材の注 入性能を式(1)等によって検証した研究結果はなく, ま た，低温における注入材の粘性や流動性，可使時間や硬 化時間等の性能は各材料開発メーカーにおいてほとんど 公開されていない.

このことから本研究では，低温における注入材の注入 性能を把握するため, 粘性と可使時間が異なる 4 種類の 注入材を用いて，温度上昇法による可使時間の算定，回 転粘度計による粘度の計測, および模擬ひび割れ供試体 への注入充填性試験を行った.

\section{4. 注入材の粘性変化の計測}

\section{（1） 注入材の可使時間の計測}

注入材の可使時間は，作業上の効率や品質確保に重要 な情報であるため，注入材の製品カタログ等の試験成績 表に公開されている。しかし，上述したように可使時間 の算定温度は $23 \pm 2^{\circ} \mathrm{C}$ での值が多い.一般にエポキシ樹 脂は温度を $10^{\circ} \mathrm{C}$ 上昇させると硬化速度が 2 倍になり， 硬化時間は $1 / 2$ 倍となる ${ }^{18)}$ ことから，低温での硬化時間 および可使時間は長くなることが推測できる。また，温 度上昇法で用いる試料の質量は一般に $100 \sim 500 \mathrm{~g}$ である が，実際の注入作業においては，例えば低圧注入器に一 度に使用する注入材の量は $30 \sim 100 \mathrm{~g}$ 程度であり，さら にひび割れ内部では注入材は拡散して広がる。このため, 注入材の量が少なくなると反応熱量も小さくなり, 硬化 時間および可使時間はより長くなると考えられる.

そこで，粘度と可使時間が異なる 4 種類の 2 液型の注 入材を用いて，環境温度を $5^{\circ} \mathrm{C}$ と $20^{\circ} \mathrm{C}$ の 2 水準，試料 の量を $30 \mathrm{~g}$ と $300 \mathrm{~g}$ の 2 水準として, 2 液混合後から硬 化までの温度上昇変化を計測し, 各注入材における可使 時間の実測を試みた。温度計測は熱電対（T 形）を使用 して 30 秒間隔で，各注入材で 2 回の計測を行った. 可 使時間は JSCE-K 541-2013 に準じて求め，計測 2 回の平 均值とした. 使用した注入材の主な諸元を表-1 に示す. これらの注入材はひび割れ注入工事で一般的に使用され 
ている製品であり，使用される頻度が比較的多い硬質系 低粘度形である．注入材 A と B は粘度が同程度で一般 に広く使用されている標準的な注入材であり，可使時間 の違いを除けば硬化後の品質もほぼ同じである.この注 入材 A と B を本実験に選定した理由は，低温の影響に よる可使時間の変化が注入充㙋性に及ぼす影響を検討す るためである．また，注入材 C と D は一般的な低粘度 形よりも粘性が低く, 低粘度形の粘度範囲に属するが超 低粘度形とも呼ばれている ${ }^{19}$. 注入材 $\mathrm{D}$ は注入材 $\mathrm{A}$ の 可使時間と同程度の注入材であり，注入材 $\mathrm{C}$ は可使時 間が短い速硬型の注入材である.ここでは注入材 C と 注入材 $\mathrm{D}$ を超低粘度形と定義する。このような超低粘 度形はひひ割れ幅が $0.2 \mathrm{~mm}$ 以下のひび割れに使用され ていることもあり，寒冷地域では低温施工時に使用され ている場合もある。本実験では，温度変化による粘度と 可使時間の変化，およびそれに伴う注入充填性を比較す るため, これら4種類の注入材を選定した.

\section{(2) 注入材の粘度計測}

可使時間の計測を行った 4 種の注入材において, 試料 $300 \mathrm{~g}$ における環境温度 $20^{\circ} \mathrm{C}, 5^{\circ} \mathrm{C}$ おび $0^{\circ} \mathrm{C}$ の 3 ケース について，2 液混合後から硬化までの注入材の経時粘度 をデジタル回転粘度計で計測した。粘度の計測は 1 秒間 隔で行い，硬化もしくは高粘度で計測不能になるまで実 施した。計測は 1 ケースで 3 回以上行い，粘度変化の過 程が類似した複数データから 1 データを選定してこれを 測定值とした。また，環境温度 $20^{\circ} \mathrm{C}$ と $5^{\circ} \mathrm{C}$ においては， 試料 $30 \mathrm{~g}$ のケースについても計測を試みた. ただし, 試料 $30 \mathrm{~g}$ での結果は使用したデジタル回転粘度計の計 測規定量以下のためここでは参考值とした.

\section{5. 注入充塡性試験}

上述した各注入材の可使時間と経時粘度の計測によっ て粘性の変化過程等を確認した後, それぞれの注入性状 と充填性状を確認するため, 図-4に示すように内径 108 $\mathrm{mm} \times$ 長さ $200 \mathrm{~mm}$ の塩化ビニル管を型枠としたコンク リート円柱供試体を作製し, 脱型せずに水中養生 28 日 後に割裂載荷によってひび割れを設けて模擬ひび割れ供 試体を作製した ${ }^{20)}$. 表-2 にコンクリートの配合を示す. 割裂載荷によって作製するひび割れ幅は $0.2 \mathrm{~mm}$ および $0.3 \mathrm{~mm}$ を基準とした。供試体に導入した割裂ひび割れ は載荷力を戻すと塩ビ管の復元力によって幅 $0.1 \mathrm{~mm}$ 程 度にまで収束するため, ひび割れの両端に $0.2 \mathrm{~mm}$ 厚, $0.3 \mathrm{~mm}$ 厚のアルミ筞を挟むことで所定のひび割れ幅を 確保した. なお，ひび割れ加工の過程で $0.25 \mathrm{~mm}$ と 0.35 $\mathrm{mm}$ となったひび割れとアルミ筞を挟まない $0.1 \mathrm{~mm}$ の模 擬ひび割れ供試体も一部作製した。補修工事でひび割れ 注入工法の選定対象となるひび割れ幅の範囲は $0.2 \sim 1.0$ $\mathrm{mm}$ であるが，低温で流動性が悪くなる注入材の性状の 影響を受けやすい $0.4 \mathrm{~mm}$ 未満の比較的狭いひび割れ幅 を対象とした。 また，試験で使用した模擬ひび割れ供試
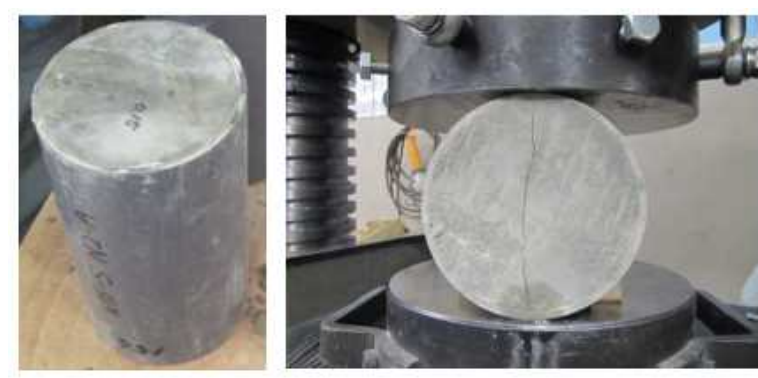

図-4 コンクリート円柱供試体の割裂状況

表-1＼cjkstart実験に使用した注入材の主な諸元

\begin{tabular}{|c|c|c|c|c|}
\hline \multirow{2}{*}{$\begin{array}{c}\text { 注入材の } \\
\text { 種類 }\end{array}$} & \multicolumn{3}{|c|}{ エポキシ樹脂系ひび割れ注入材 硬質系低粘度形 } \\
\cline { 2 - 5 } & \multicolumn{2}{|c|}{ 低粘度形 } & \multicolumn{2}{|c|}{ 超低粘度形 } \\
\hline 記号 & $\mathrm{A}$ & $\mathrm{B}$ & $\mathrm{C}$ & $\mathrm{D}$ \\
\hline $\begin{array}{c}\text { 粘度 } \\
(\mathrm{dPa} \cdot \mathrm{s})\end{array}$ & $5.94\left(20^{\circ} \mathrm{C}: 500 \mathrm{~g}\right)$ & $6.4\left(23 \pm 2^{\circ} \mathrm{C}: 150 \mathrm{~g}\right)$ & $1.5 \sim 5.0\left(20^{\circ} \mathrm{C}: 100 \mathrm{~g}\right)$ & $\begin{array}{c}2.7\left(5^{\circ} \mathrm{C}: 500 \mathrm{~g}\right) \\
1.1\left(20^{\circ} \mathrm{C}: 500 \mathrm{~g}\right)\end{array}$ \\
\hline $\begin{array}{c}\text { 可使時間 } \\
(\mathrm{min})\end{array}$ & $50\left(20^{\circ} \mathrm{C}: 500 \mathrm{~g}\right)$ & $150\left(23 \pm 2^{\circ} \mathrm{C}: 150 \mathrm{~g}\right)$ & $\begin{array}{c}40\left(10^{\circ} \mathrm{C}: 100 \mathrm{~g}\right) \\
14\left(20^{\circ} \mathrm{C}: 100 \mathrm{~g}\right)\end{array}$ & $40 \pm 10\left(20^{\circ} \mathrm{C}: 500 \mathrm{~g}\right)$ \\
\hline
\end{tabular}

※Aは材料メーカーの試験成績值， B， C，Dはカタログ值

表-2 コンクリートの配合

\begin{tabular}{|c|c|c|c|c|c|c|c|c|c|c|}
\hline \multirow{2}{*}{$\begin{array}{c}\text { セメント } \\
\text { の種類 }\end{array}$} & \multirow{2}{*}{$\begin{array}{l}\text { Gmax } \\
(\mathrm{mm})\end{array}$} & \multirow{2}{*}{$\begin{array}{l}\mathrm{W} / \mathrm{C} \\
(\%)\end{array}$} & \multirow{2}{*}{$\begin{array}{l}\mathrm{S} / \mathrm{a} \\
(\%)\end{array}$} & \multicolumn{4}{|c|}{ 単位量 $\left(\mathrm{kg} / \mathrm{m}^{3}\right)$} & \multirow{2}{*}{$\begin{array}{l}\text { Slump } \\
(\mathrm{cm})\end{array}$} & \multirow{2}{*}{$\begin{array}{l}\text { Air } \\
(\%)\end{array}$} & \multirow{2}{*}{$\begin{array}{c}\mathrm{Cl}^{-} \\
\left(\mathrm{kg} / \mathrm{m}^{3}\right)\end{array}$} \\
\hline & & & & $\mathrm{W}$ & $\mathrm{C}$ & $\mathrm{S}$ & $\mathrm{G}$ & & & \\
\hline $\mathrm{OPC} *$ & 20 & 52.1 & 43.8 & 156 & 300 & 812 & 1032 & 7.5 & 5.5 & 0.054 \\
\hline
\end{tabular}

※普通ポルトランドセメント 
供試体に注入材を注入

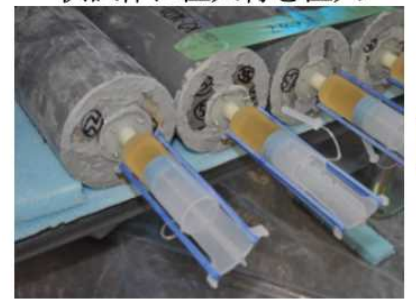

深さ $5 \mathrm{~cm}$ 毎に供試体を切断

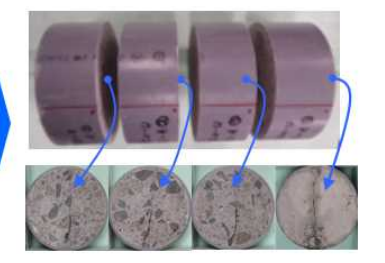

注入材の充填分布と充䪺率を測定

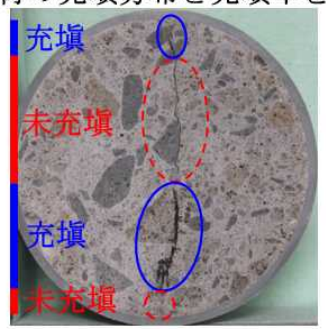

充堪率 $(\%)=\frac{\text { 充填された長さ }}{\text { 円柱供試体の内径 }} \times 100$

図-5 注入充塡性試験の状況と充填率の定義

表-3 注入充垻性試験の試験ケース

\begin{tabular}{|c|c|c|c|c|c|c|c|}
\hline \multicolumn{4}{|c|}{ 試験条件 } & \multicolumn{4}{|c|}{ ひび割れ注入材の種類 } \\
\hline \multicolumn{3}{|c|}{ 実験開始時の温度 $\left({ }^{\circ} \mathbf{C}\right)$} & \multirow{2}{*}{$\begin{array}{c}\text { ひび割れ幅 } \\
\text { (mm) }\end{array}$} & \multirow[b]{2}{*}{$\mathbf{A}$} & \multirow[b]{2}{*}{ B } & \multirow[b]{2}{*}{ C } & \multirow[b]{2}{*}{ D } \\
\hline $\begin{array}{c}\text { 環境温度 } \\
\text { (室温) }\end{array}$ & 供試体 & 注入材 & & & & & \\
\hline \multirow{3}{*}{20} & \multirow{3}{*}{20} & \multirow{3}{*}{20} & 0.1 & A2020_0.1 & - & - & - \\
\hline & & & 0.2 & A2020_0.2 & B2020_0.2 & C2020_0.2 & D2020_0.2 \\
\hline & & & 0.3 & A2020_0.3 & B2020_0.3 & C2020_0.3 & - \\
\hline \multirow{3}{*}{5} & \multirow{3}{*}{5} & \multirow{3}{*}{5} & 0.2 & A0505_0.2 & B0505_0.2 & C0505_0.2 & D0505_0.2 \\
\hline & & & 0.3 & A0505_0.3 & B0505_0.3 & C0505_0.3 & - \\
\hline & & & 0.35 & A0505_0.35 & B0505_0.35 & C0505_0.35 & - \\
\hline \multirow{4}{*}{5} & \multirow{4}{*}{$\mathbf{0}$} & \multirow{4}{*}{5} & 0.2 & A0005_0.2 & B0005_0.2 & C0005_0.2 & D0005_0.2 \\
\hline & & & 0.25 & - & B0005_0.25 & C0005_0.3 & - \\
\hline & & & 0.3 & A0005_0.3 & B0005_0.3 & - & - \\
\hline & & & 0.35 & A0005_0.35 & - & - & - \\
\hline
\end{tabular}

体は，数多くの供試体を割裂した中から比較的直線的に ひび割れが発生した供試体を選定した。

これらの模擬ひび割れ供試体を用いて，一面から注入 材を注入して背面から排出するまでの注入時間を計測し, さらに硬化後に注入材の充填状態を確認寸る実験を行っ た.これを注入充填性試験と定義する. 注入充填性試験 は，図-5 に示寸ように模擬ひび割れ供試体の一面（注 入面）から注入材を $30 \mathrm{~g}$ 入れた注入器で自動低圧注入 を行って排出するまでの注入時間を計測し，その後，注 入器を付けたまま 1 週間以上養生した。 なお, 注入は供 試体のひび割れを縦にした状態で側面に注入する方法と し, 注入器はゴムの伸縮で自動低圧注入するシリンダー タイプを用いた. 養生後, 注入材が完全に硬化している ことを確認してから，供試体の注入面から深さ方向に $50 \mathrm{~mm}$ 間隔で切断し, 切断面のひび割れに充填されてい る注入材の充填率を拡大鏡を用いて目視計測した. 充填 率は内径 $108 \mathrm{~mm}$ の供試体のひび割れに対して $1 \mathrm{~mm}$ 毎 に注入材の充塡の有無を計測し, 充填されていた長さの 総計を内径 $108 \mathrm{~mm}$ で除した值とした. また, 内径 108 $\mathrm{mm}$ のひび割れ長さに対して注入材が充填されている位 置の分布も調べた（以下，充顚分布）.

表-3 に試験ケースを示す。試験は, 実験室（恒温
室) 内の環境温度を $20^{\circ} \mathrm{C}$ と $5^{\circ} \mathrm{C}$ の 2 水準で行い, 実験 開始時の供試体の温度を $20^{\circ} \mathrm{C}, 5^{\circ} \mathrm{C}, 0^{\circ} \mathrm{C}$ の 3 水準，実 験開始時の注入材の温度は環境温度に合わせて $20^{\circ} \mathrm{C}$ と $5^{\circ} \mathrm{C}$ の 2 水準とした. 供試体のひび割れ幅は $0.1 \sim 0.35$ $\mathrm{mm}$ の範囲とした. なお, $20^{\circ} \mathrm{C}$ と $5^{\circ} \mathrm{C}$ の供試体と混合前 の注入材の温度は, 室温 $20^{\circ} \mathrm{C}$ と $5^{\circ} \mathrm{C}$ の実験室に静置し て表面温度が室温と同じ温度になってから 2 液の注入材 を混合して注入充塡性試験を開始した．また， $0^{\circ} \mathrm{C}$ の供 試体は, $-20^{\circ} \mathrm{C}$ の冷凍室で半日冷凍した後, 室温 $5^{\circ} \mathrm{C}$ の 実験室に静置して供試体の表面温度が $0^{\circ} \mathrm{C}$ ま早した 時点で試験を開始した，なお，注入器は低温によるシー ル材の付着力低下を防ぐため, $20^{\circ} \mathrm{C}$ の実験室で先に注 入器を接着させてから各供試体の温度管理を実施した。

試験は各ケース 1 供試体で行い, ひび割れ幅 $0.2 \mathrm{~mm}$ は全ての注入材で実施し,ひび割れ幅 $0.3 \mathrm{~mm}$ は注入材 A，B，Cで実施した．その他のひび割れ幅 $0.1 \mathrm{~mm}, 0.25$ $\mathrm{mm}, 0.35 \mathrm{~mm}$ においては各注入材でランダムに実施し た。 なお，注入圧力を測定する実験を注入材 $\mathrm{A}$ におい てひび割れ幅 $0.2 \mathrm{~mm}$ と $0.3 \mathrm{~mm}$ の 3 供試体で事前に実施 した. その結果, 注入圧力はひび割れ幅 $0.2 \mathrm{~mm}$ で 0.07 $\mathrm{MPa}$ ひび割れ幅 $0.3 \mathrm{~mm}$ で $0.06 \mathrm{MPa}$ と $0.08 \mathrm{MPa}$ となり, 平均注入圧力は $0.07 \mathrm{MPa}$ であった. 


\section{6. 実験結果}

\section{（1）各注入材の可使時間の算定}

図-6 に各環境温度における各注入材の温度変化を示 す．環境温度 $20^{\circ} \mathrm{C}$ において，試料 $300 \mathrm{~g}$ で測定した各注 入材の温度上昇傾向は, 注入材 $\mathrm{B}$ は緩やかな温度上昇, 注入材 $\mathrm{A} ， \mathrm{C}, \mathrm{D}$ は急激に温度が上昇する傾向を示した。 一方，試料 $30 \mathrm{~g}$ で測定した試験ケースでは，急激に温 度上昇した注入材 $\mathrm{C}$ 以外は温度がほとんど上昇しない 状態で硬化に至った。

次に，環境温度 $5^{\circ} \mathrm{C}$ において，試料 $300 \mathrm{~g}$ の試験ケー スでは，超低粘度形の 2 種類（注入材 $\mathrm{C}$ と D）に温度上 昇が見られた。注入材 $\mathrm{C}$ は急激に温度が上昇し，注入
材 D は緩やかに温度が上昇した。一方，低粘度形の注 入材 $\mathrm{A}$ と B は温度がほとんど上昇しなかった。また， 試料 $30 \mathrm{~g}$ の少量ではすべての注入材で温度がほとんど 上昇しない結果となった.

このように低温もしくは少量において温度上昇が見ら れなかった注入材はエポキシ樹脂の反応熱量が少ない一 方で，硬化速度が速い注入材 $\mathrm{C}$ のような注入材は反応 熱量が多いと考えられる。これらの温度変化傾向から JSCE-K 541-2013 の温度上昇法に準拠した可使時間の算定 值を求めた結果を表-4 に示す．環境温度 $20^{\circ} \mathrm{C}$ における 注入材 $\mathrm{A}$ の可使時間は 73.5 分，注入材 $\mathrm{B}$ は 201 分，注 入材 $\mathrm{C}$ は 26.6 分, 注入材 $\mathrm{D}$ は 80.5 分となり，表-1 に示 した標準的な可使時間に比較的近い值となった。しかし，
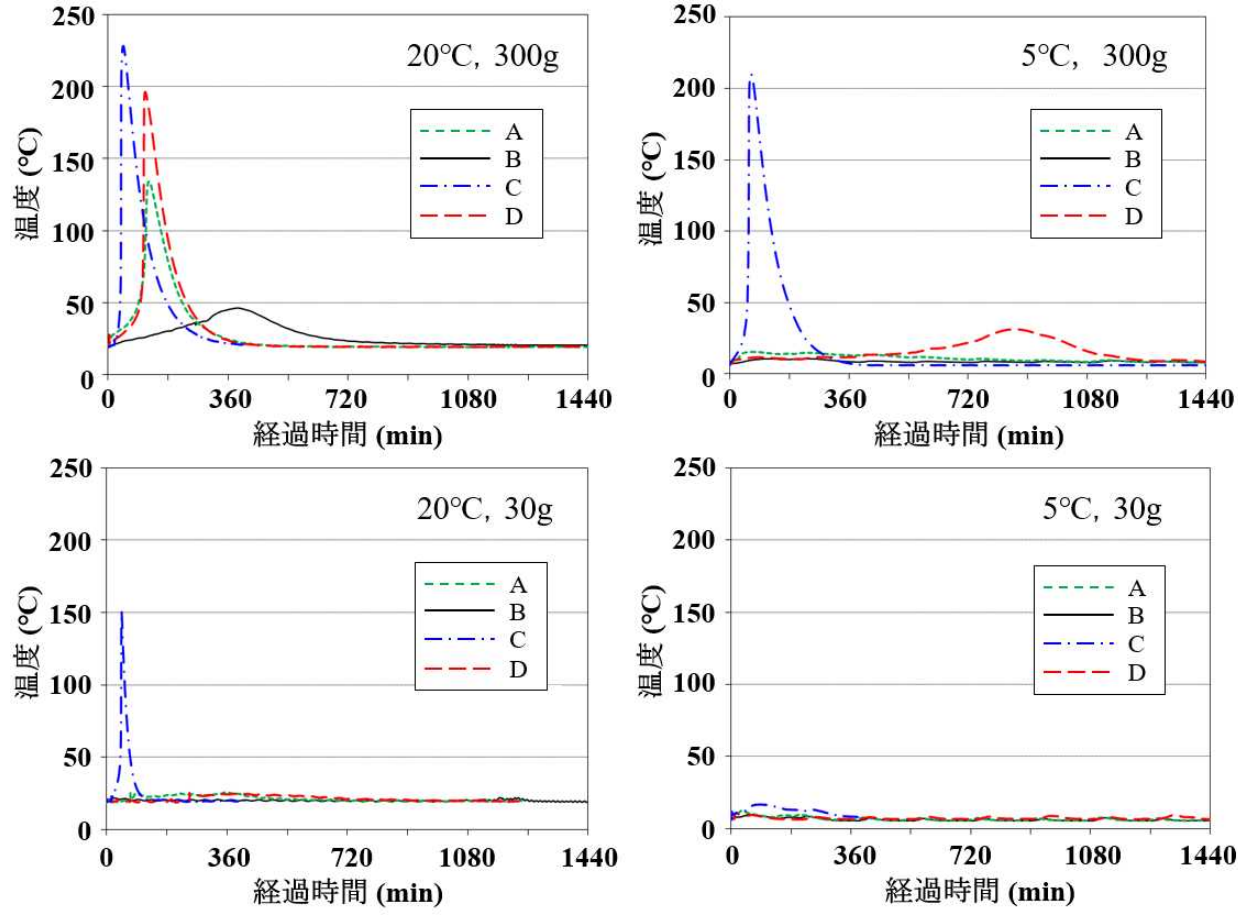

図-6 各注入材の温度変化

表-4＼cjkstart温度上昇法による可使時間の算定値

\begin{tabular}{|c|c|c|c|c|c|}
\hline $\begin{array}{l}\text { 試験 } \\
\text { 条件 }\end{array}$ & $\begin{array}{l}\text { 環境 } \\
\text { 温度 }\end{array}$ & \multicolumn{2}{|l|}{$20^{\circ} \mathrm{C}$} & \multicolumn{2}{|c|}{$5^{\circ} \mathrm{C}$} \\
\hline 試料 & 注入材 & 算定方法 & $\begin{array}{l}\text { 算定値 } \\
\text { (min) }\end{array}$ & 算定方法 & $\begin{array}{l}\text { 算定値 } \\
\text { (min) }\end{array}$ \\
\hline \multirow{4}{*}{$300 \mathrm{~g}$} & $\mathbf{A}$ & 急上昇点までの70\% & 73.5 & 温度上昇なし & - \\
\hline & B & 最高温度までの50\% & 201 & 温度上昇なし & - \\
\hline & C & 急上昇点までの $70 \%$ & 26.6 & $\begin{array}{c}\text { 急上昇点までの } \\
\mathbf{7 0 \%}\end{array}$ & 39.2 \\
\hline & D & 急上昇点までの $70 \%$ & 80.5 & $\begin{array}{c}\text { 最高温度までの } \\
\mathbf{5 0 \%}\end{array}$ & 429.5 \\
\hline \multirow{4}{*}{$30 \mathrm{~g}$} & $\mathbf{A}$ & 温度上昇なし & - & 温度上昇なし & - \\
\hline & B & 温度上昇なし & - & 温度上昇なし & - \\
\hline & $\mathrm{C}$ & 急上昇点までの $70 \%$ & 30.1 & 温度上昇なし & - \\
\hline & D & 温度上昇なし & - & 温度上昇なし & - \\
\hline
\end{tabular}


低温環境や少量では温度が上昇しない注入材が多いこと から，低温環境では温度上昇法によって可使時間を評価 できないと結論づけられる.

\section{(2) 各注入材の粘度の経時変化}

図-7 に各環境温度における各注入材の粘度の経時変 化を示す．環境温度 $20^{\circ} \mathrm{C}$ では, 注入材 $\mathrm{A}$ と $\mathrm{B}$ は粘度が 若干低下した後, 徐々に粘度が増加し始めて途中で急に 大きく増加して硬化に至った. 注入材 C と D は粘度が 低下した後, 急激に粘度が増加して硬化した。擋拌直後 に粘度が若干低下寸る現象は，反応が始まって発熱し始 めたことによって注入材が温まり，初期粘度よりも一時 的に粘度が低下寸ることで生じる. また，その後，急激 に発熱量が多くなって硬化速度が増加して粘度が増加し， 一気に硬化に至る現象は反応型樹脂の特有の性状である. この環境温度 $20^{\circ} \mathrm{C}$, 試料 $300 \mathrm{~g}$ において各注入材の粘度 が急激に増加し始めた経過時間は, 前項の温度上昇法で 算定した可使時間に近い值となった。

一方, 環境温度 $5^{\circ} \mathrm{C}$ およ゙ $0^{\circ} \mathrm{C}$ における各注入材の粘 度の経時変化は, 注入材 $\mathrm{C}$ を除いて, 注入材 $\mathrm{A}, \mathrm{B}, \mathrm{D}$ は擋汼直後の粘度低下は見られるが，その後の粘度の上 昇傾向は徐々に増加して硬化に至る傾向に変化した。さ らに，計測終了までの経過時間も低温になるほど長くな った. これは, 前項の可使時間を算定する温度変化の試 験結果から，低温によって硬化反応の発熱が抑えられた ためと考えられ，言い換えれば，発熱の影響を受けずに 硬化が進む低温時の注入材の性能を表していると言える.

また，参考值とした環境温度 $20^{\circ} \mathrm{C}$ および $5^{\circ} \mathrm{C}$ の試料 $30 \mathrm{~g}$ における粘度の経時変化は, $300 \mathrm{~g}$ よりも粘度の増 加が緩やかとなり経過時間も少し長くなっている。これ
は反応熱量が少ないためと推測できるが, 少量であって も環境温度が可使時間に及ぼす影響は大きいことがわか った.

以上のことから, 低温環境で注入材が少量では温度上 昇がほとんどない状態で硬化反応が進行することから， ひび割れ内部ではほとんど温度上昇しない状態で注入材 が注入・充填されると思われる。したがって，ひび割れ 内部の注入材の注入充填性は, 注入量に関わらずひび割 れ内部の環境温度に依存すると推測する.

\section{(3) 注入充堙性試験}

注入充填性試験の各試験ケースにおいて, 注入開始か ら背面に排出するまでの注入時間を図-8 および図-9 に 示す. 図-8 はひび割れ幅の変化による注入時間の変化, 図-9 はひび割れ幅 $0.2 \mathrm{~mm}$ と $0.3 \mathrm{~mm}$ における環境温度の 変化による注入時間の変化に着目した. 排出なしのケー スを除いた試験ケース寸べてにおいて，環境温度に関わ らずひび割れ幅が大きくなると注入時間は短くなる.ま た，ひび割れ幅が同じ場合，環境温度が低くなるにつれ て注入時間は大きく増加することから，注入材の流動性 はひび割れ幅と環境温度に大きく影響されることがわか る. 注入時間が一番長くなった注入材 $\mathrm{A}$ のひび割れ幅 $0.2 \mathrm{~mm}$ では, $200 \mathrm{~mm}$ の距離に対して注入材の排出まで $0^{\circ} \mathrm{C}$ で 6 時間弱もかかっており, $5^{\circ} \mathrm{C}$ でも約 1 時間半か かることから，低温での施工では施工性が極端に低下寸 ることが明らかである. 注入材 $\mathrm{B} の 0^{\circ} \mathrm{C}$ も注入時間は長 くなったが，可使時間が長いため注入材 A よりも注入 時間は短くなった. 一方, 超低粘度形の注入材 $\mathrm{C}$ は, 環境温度 $5^{\circ} \mathrm{C}$ において注入材 $\mathrm{A}$ および $\mathrm{B}$ の $20^{\circ} \mathrm{C}$ よりも 短い注入時間で排出しており, $5^{\circ} \mathrm{C}$ 程度の低温環境では
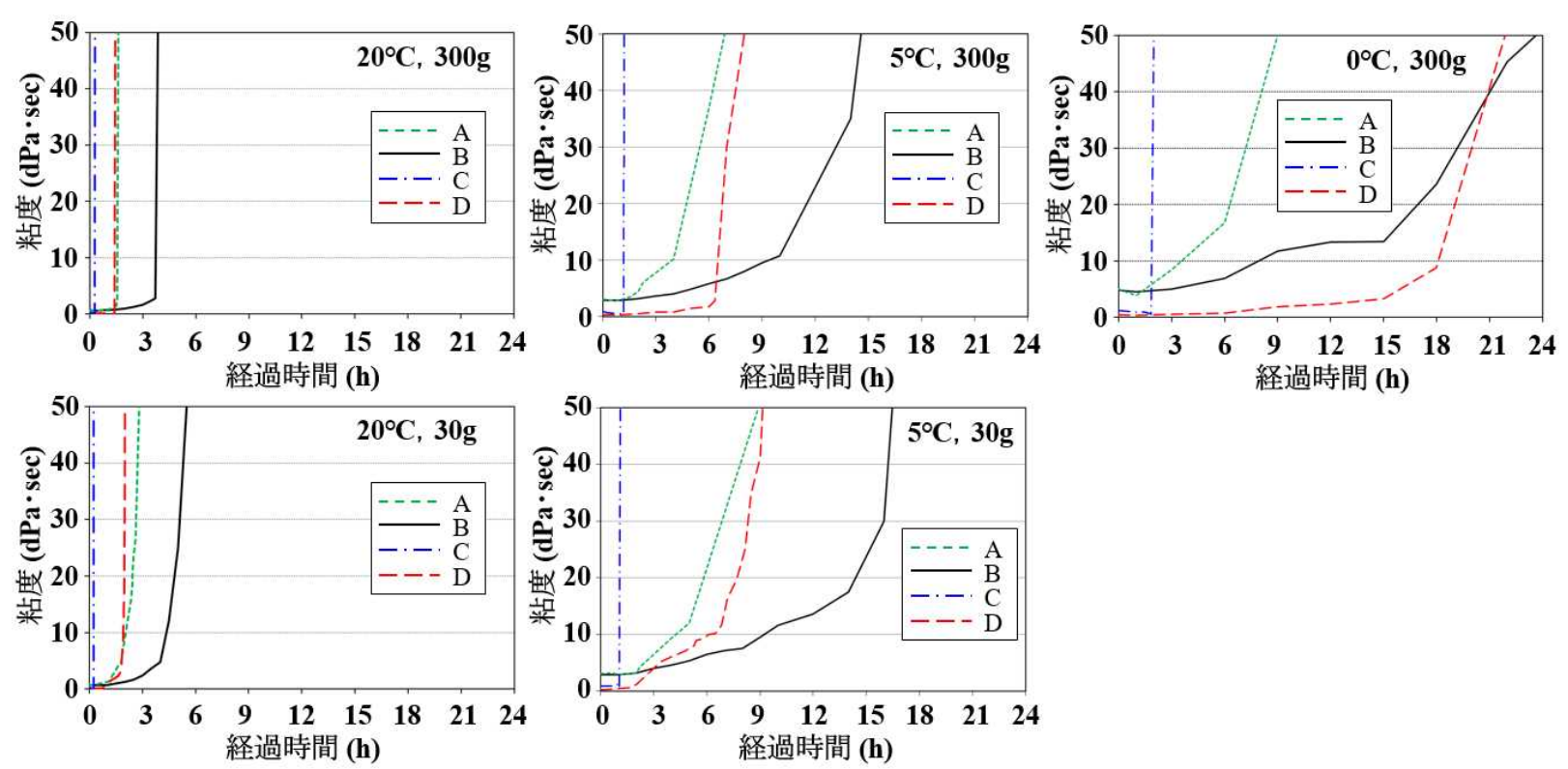

図-7 各注入材の経時粘度 


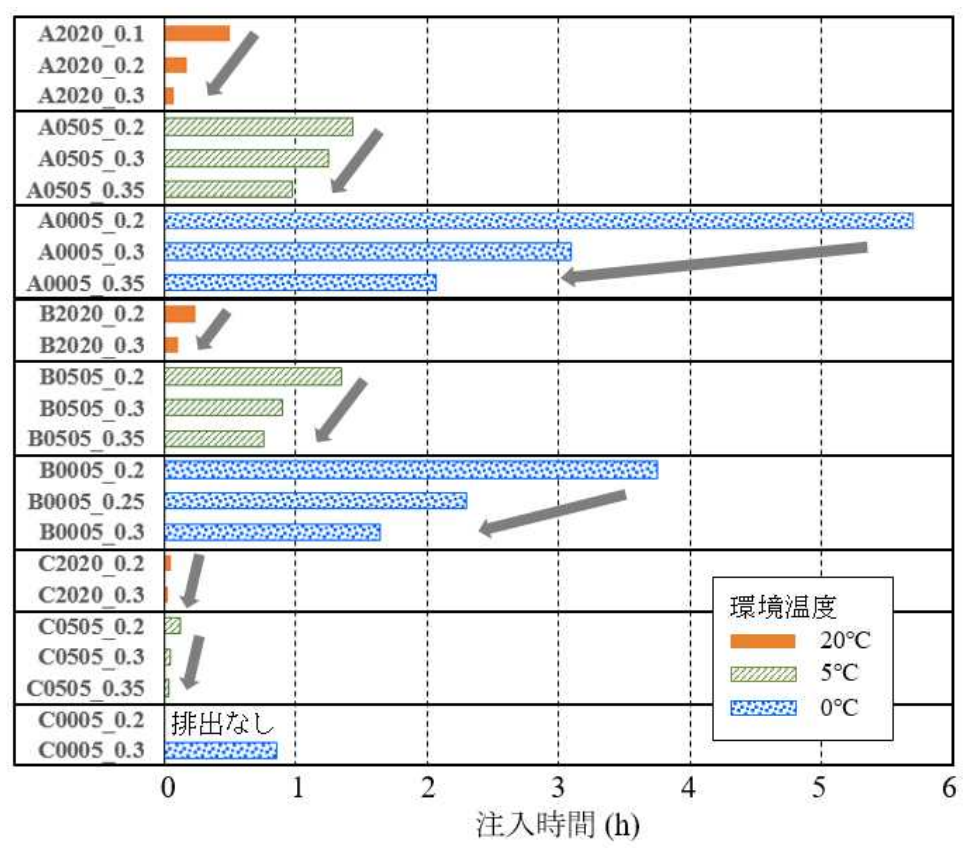

図-8 ひび割れ幅の変化による注入時間の変化

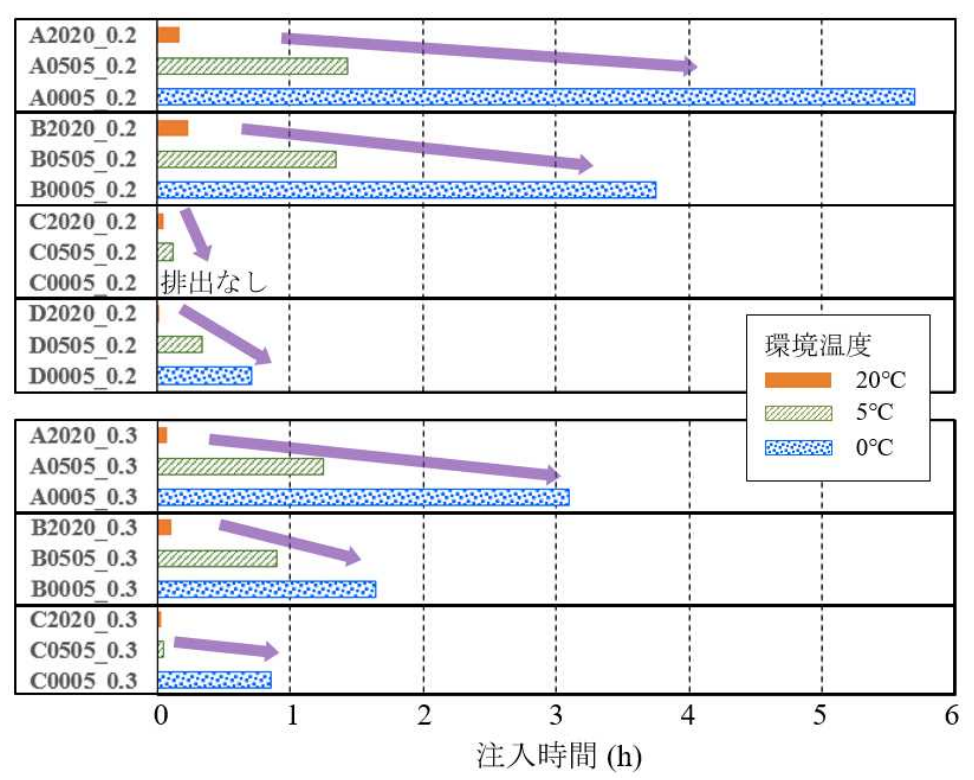

図-9 ひび割れ幅 $0.2 \mathrm{~mm}$ と $0.3 \mathrm{~mm}$ の環境温度の変化による注入時間の変化

施工性が良いと言えるが，環境温度 $0^{\circ} \mathrm{C}$ のひび割れ幅 $0.2 \mathrm{~mm}$ では注入材は排出しなかった。注入材 $\mathrm{D}$ は $0^{\circ} \mathrm{C}$ のひび割れ幅 $0.2 \mathrm{~mm}$ でも 1 時間以内に排出したことか ら，低温でも施工性が良い結果となった。

次に，図-10 に注入材が硬化した後の供試体のひび割 れに充填された注入材の測定断面毎の充填率を示す。ま た，図-11に各測定断面に充塡された注入材の充填分布 のイメージ図の一例を示す．排出面である深さ $200 \mathrm{~mm}$ の充塤率が全体的に若干低下寸る傾向がみられた。これ は，排出面のひび割れが開放されていたことが影響して
いると思われるが，低温で注入材の粘度が増加してもひ び割れ幅が大きいほうが充塡率が低下している. 図-11 の充填分布から，排出口付近の充壃率の低下は，ひび割 れの上部に充填されていない状態とひび割れの上下部に 充填されていない状態の 2 パターンがあり，これは注入 材の排出によって注入圧が低下して排出口で注入材が流 下した，もしくは上下に拡散できずに排出されたためと 推測する.

注入材別にみると, 注入材 $\mathrm{A}$ と $\mathrm{B}$ は環境温度に関わ らず充填率は比較的高い結果となった。注入材 $\mathrm{C}$ はひ 


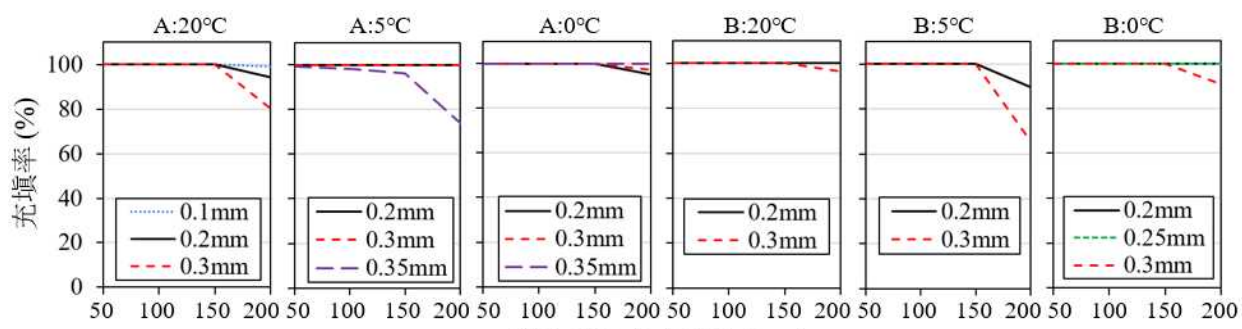

注入面からの樑さ $(\mathrm{mm})$

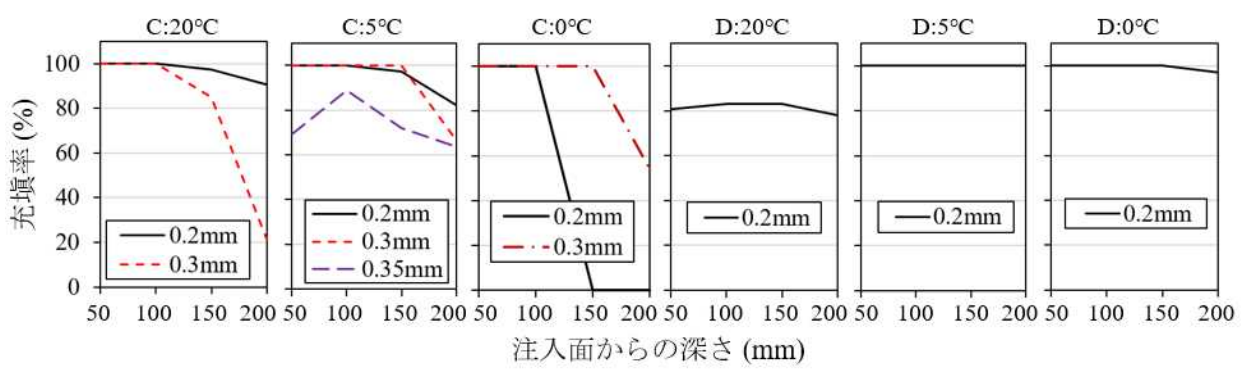

図-10 注入充填性試験における注入材の充填率

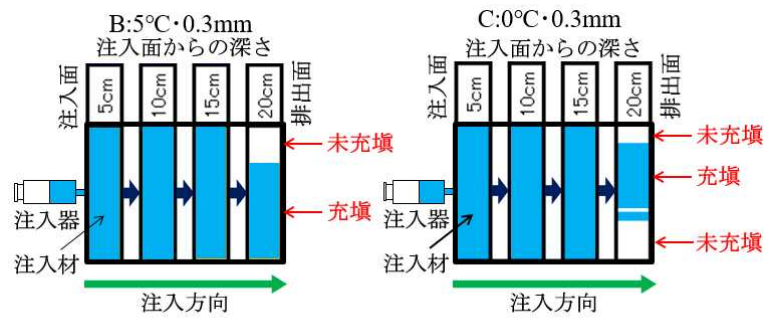

図-11 注入材の充填状態のイメージ図例

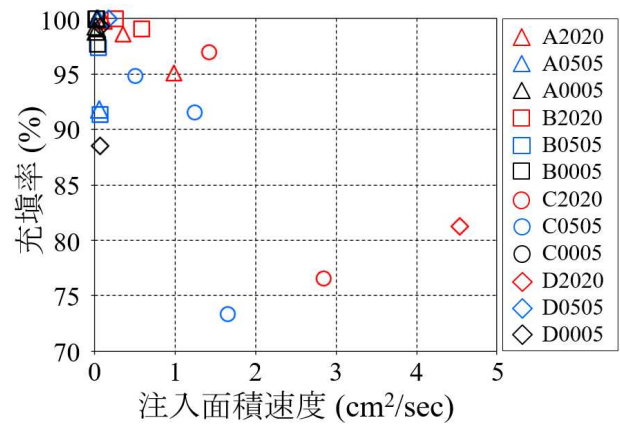

図-12 注入面積速度の実測值と充填率の関係

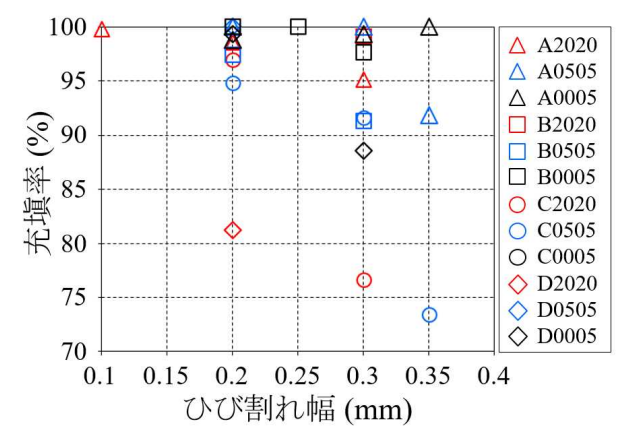

図-13 ひび割れ幅と充填率の関係
び割れ幅が大きいほど充填率は低下した。なお，環境温 度 $0^{\circ} \mathrm{C}$ のひび割れ幅 $0.2 \mathrm{~mm}$ のケースでは注入材の排出 がなかった。注入材 $\mathrm{D}$ は低温の $5^{\circ} \mathrm{C}$ と $0^{\circ} \mathrm{C}$ ではほぼ充坥 されているが， $20^{\circ} \mathrm{C}$ では注入口から流下して上部に拡 散しなかったために充填率が低下している.

\section{(4) 注入面積速度と充塡率}

図-12 に注入充填性試験で得られた注入面積速度の実 測值と充填率の関係，および図-13 にひび割れ幅と充填 率の関係を示す。ここで注入面積速度は注入面積を注入 時間で除した值とした。なお，注入時間は供試体の排出
面に注入材が到達して排出を確認した時間とし，注入面 積は実際に充填されていた面積ではなく，図-14 に示す ように，ひび割れが供試体の中心に屈曲せずに位置して いると仮定して注入材が注入口から同心円状に拡散しな がら充填されて排出面に到達した時点での状態を想定し た面積とした。図-12 から，実測值の注入面積速度が速 くなると充壃率が低下する傾向がみられ， $20^{\circ} \mathrm{C}$ の超低 粘度の 2 ケースで流下による充塡率の低下はあるが，低 温のケースのほうが充填率は低い傾向がみられた。また， 図-13 においても，20ㄷ の超低粘度の 2 ケースを除いて 低温のケースで充填率が低くなっている. これは，上述 


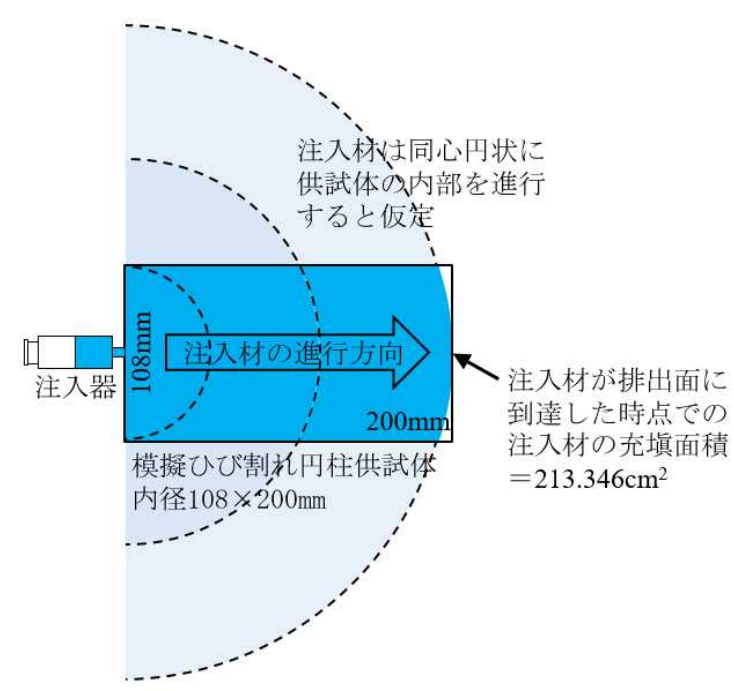

図-14 注入材が供試体に充填されるイメージ図と充填面積

した実構造物での調査結果である図-2 と同様に，比較 的ひび割れ幅が狭い幅 $0.35 \mathrm{~mm}$ 以下のひび割れ注入では 充填が不十分になるケースがあることを確認できたと言 える．実際の低温環境の施工では，硬化が速い注入材や 粘度の低い注入材を使用する傾向があるため, 図-12 お よび図-13 で示した低温でもひび割れ幅が大きいと流下 する，あるいは途中で硬化してしまうことで充填率の低 下を招いていると推測する。 そこで，低温環境における 各種注入材の注入充填性に関する性能評価を既往の研究 で提案された注入面積速度の式(1)によって検討した結 果を以降で考察する.

\section{7. 低温環境における注入材の性能評価}

\section{(1) 注入面積速度と補正係数の算出}

実測值から求めた注入面積速度と注入面積速度の式 (1)による計算值との相関を求めて補正係数 $\alpha$ の算出を試 みた。注入面積速度は，各試験ケースで設定したひび割 れ幅 $w(\mathrm{~cm})$, 各環境温度で測定した注入材の経時粘度 $\mu$ $(\mathrm{Pa} \cdot \mathrm{sec})$ ，および注入圧 $p(\mathrm{~Pa})$ をそれぞれ代入し，そし て補正係数 $\alpha$ を除いた注入面積速度 $w^{2} p / \mu\left(\mathrm{cm}^{2} / \mathrm{sec}\right)$ を 求めた。なお，注入圧は事前の実験で得られた平均值 $0.07 \mathrm{MPa}(70000 \mathrm{~Pa})$ とした.

図-15 に実測値の注入面積速度と式(1)により得られた 注入面積速度の関係を示す。この関係において試験ケー スによっていくつかの相関に分類できる傾向がみられた. これらを分類するとひび割れ幅に関わらず注入材の種類 と環境温度で大別でき，それぞれを最小二乗法による回 帰直線で表すと概ね相関が得られる結果となった。 それ ぞれの相関をグループ G1，G2，G3 として，表-5に分類 したグループ毎の試験ケースを示す.グループ G1 は環

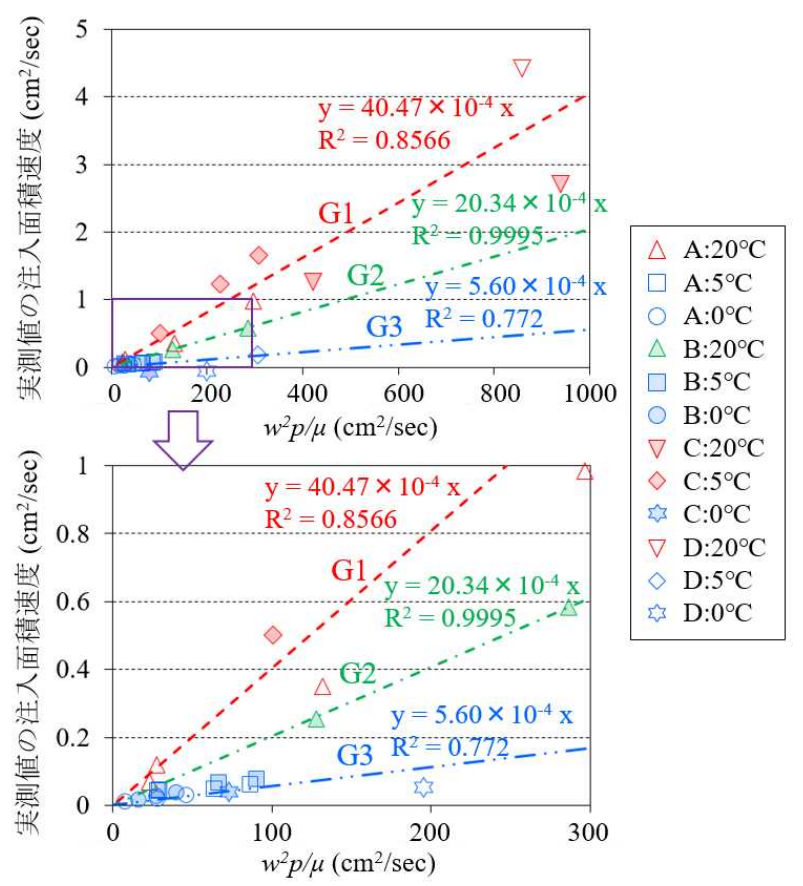

図-15 注入面積速度の実測值と $w^{2} p / \mu$ の関係

表-5 注入面積速度の実測值と $w^{2} p / \mu$ の関係から得られた試験 ケースのグループ分け

\begin{tabular}{|c|c|c|c|c|}
\hline \multirow{2}{*}{ グループ } & \multicolumn{4}{|c|}{ ひび割れ注入材の種類 } \\
\hline & $\mathbf{A}$ & B & $\mathrm{C}$ & D \\
\hline \multirow{5}{*}{ G1 } & A2020_0.1 & - & C2020_0.2 & D2020_0.2 \\
\hline & A2020_0.2 & - & C2020_0.3 & - \\
\hline & A2020_0.3 & - & C0505_0.2 & - \\
\hline & - & - & C0505_0.3 & - \\
\hline & - & - & C0505_0.35 & - \\
\hline \multirow{2}{*}{ G2 } & - & B2020_0.2 & - & - \\
\hline & - & B2020_0.3 & - & - \\
\hline \multirow{6}{*}{ G3 } & A0505_0.2 & B0505_0.2 & C0005_0.2 & D0505_0.2 \\
\hline & A0505_0.3 & B0505_0.3 & C0005_0.3 & D0005_0.2 \\
\hline & A0505_0.35 & B0505_0.35 & - & - \\
\hline & A0005_0.2 & B0005_0.2 & - & - \\
\hline & A0005_0.3 & B0005_0.25 & - & - \\
\hline & A0005_0.35 & B0005_0.3 & - & - \\
\hline
\end{tabular}

境温度 $20^{\circ} \mathrm{C}$ の注入材 $\mathrm{A}, \mathrm{D}$, および環境温度 $20^{\circ} \mathrm{C}$ と $5^{\circ} \mathrm{C}$ の注入材 $\mathrm{C}$, グループ $\mathrm{G} 2$ は環境温度 $20^{\circ} \mathrm{C}$ の注入材 $\mathrm{B}$ ，グループ $\mathrm{G} 3$ は環境温度 $5^{\circ} \mathrm{C}$ と $0^{\circ} \mathrm{C}$ の注入材 $\mathrm{A}, \mathrm{B}$, $\mathrm{D}$ ，およひ環境温度 $0^{\circ} \mathrm{C}$ の注入材 $\mathrm{C}$ である. 各グループ の特徵は，グループ G1 は温度上昇法において急激に温 度が上昇した注入材, グループ $\mathrm{G} 2$ は徐々に温度が上昇 した注入材であり，グループ G3 は低温環境では温度が 上昇しなかった注入材，いわゆる温度上昇法では可使時 間が測定できなかった注入材である.それぞれの回帰直 線の係数は注入面積速度の補正係数 $\alpha$ となることから, 注入材の温度上昇の有無によって補正係数は異なること がわかる．この結果から，グループ G3，すなわち低温 環境における注入材の注入性能は補正係数 $\alpha=5.60 \times 10^{4}$ 
を用いた注入面積速度で表せることが確認できた。

\section{(2) 硬化までの到達距離の算出}

次に, 各試験ケースで注入材が硬化するまでに到達す る推定距離を求めた. 実測した注入材の粘度の経時変化 を用いて硬化までの注入面積速度の経時変化を式(1)か ら求め，到達距離は，直径 $108(\mathrm{~mm}) \times$ 長さ $L_{n}(\mathrm{~mm})$ の円 柱供試体のひび割れに注入すると仮定して注入面積を $108 \mathrm{~mm}$ で除した值 $L_{n} / 108(\mathrm{~mm})$ とした．各試験ケースの 到達距離を表-6 に，一例として注入材 A の経過時間と 到達距離の関係を図-16に示す，環境温度 $20^{\circ} \mathrm{C}$ では，ひ

表-6 各試験ケースにおける到達距離

\begin{tabular}{|c|c|c|c|c|c|}
\hline \multicolumn{2}{|c|}{ ひび割れ幅 $(\mathbf{m m})$} & 0.1 & 0.2 & 0.3 & 0.35 \\
\hline 注入材 & 環境温度 & \multicolumn{4}{|c|}{ 到達距離 $(\mathbf{m m})$} \\
\hline \multirow{4}{*}{$\mathrm{A}$} & $20^{\circ} \mathrm{C}$ & 160.7 & 635.5 & 1426.8 & 1941.2 \\
\cline { 2 - 6 } & $5^{\circ} \mathrm{C}$ & 21.7 & 79.2 & 175.2 & 237.6 \\
\cline { 2 - 6 } & $0^{\circ} \mathrm{C}$ & 15.7 & 55.4 & 121.5 & 164.5 \\
\hline \multirow{4}{*}{ B } & $20^{\circ} \mathrm{C}$ & 178.5 & 706.7 & 1587.0 & 2159.2 \\
\cline { 2 - 6 } & $5^{\circ} \mathrm{C}$ & 35.4 & 134.3 & 299.1 & 406.2 \\
\cline { 2 - 6 } & $0^{\circ} \mathrm{C}$ & 34.7 & 131.4 & 292.5 & 397.2 \\
\hline \multirow{4}{*}{$\mathrm{C}$} & $20^{\circ} \mathrm{C}$ & 168.0 & 664.6 & 1492.2 & 2030.1 \\
\cline { 2 - 6 } & $5^{\circ} \mathrm{C}$ & 115.3 & 454.0 & 1018.4 & 1385.3 \\
\cline { 2 - 6 } & $0^{\circ} \mathrm{C}$ & 29.3 & 109.9 & 244.2 & 331.6 \\
\hline \multirow{4}{*}{ D } & $2^{\circ} \mathrm{C}$ & 1284.6 & 5131.1 & 11541.9 & 15708.9 \\
\cline { 2 - 6 } & $5^{\circ} \mathrm{C}$ & 91.3 & 357.9 & 802.2 & 1091.0 \\
\cline { 2 - 6 } & $0^{\circ} \mathrm{C}$ & 234.8 & 931.8 & 2093.4 & 2848.5 \\
\hline
\end{tabular}

び割れ幅が広く粘度が低い注入材ほど到達距離は長くな るが，急激な硬化によって流動が止まる．環境温度 $5^{\circ} \mathrm{C}$

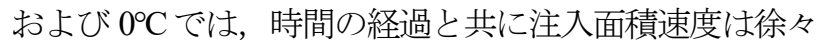
に遅くなり到達距離が途中でほとんど伸びなくなってや がて流動が停止する．なお，注入材 $\mathrm{C}$ は初期粘度は低 いが可使時間が短いために温度が低くても急に停止して いる. これらの停止距離もしくは停滞距離が各注入材の 環境温度とひび割れ幅における注入可能な限界距離とな り，低温環境では注入材 $\mathrm{D}$ を除いて注入可能な距離は 一様に短くなる傾向となる，このことから，低温環境で は施工数量や規模が同じでも $20^{\circ} \mathrm{C}$ 前後の温度環境より も到達距離が短くなり, 目標到達までの経過時間も異な ることがわかる.

\section{（3）低温環境における注入充塤性の事前評価の一例}

上記の結果から, 低温環境における注入材の性能を事 前に確認寸る手法を検討した. 表-7 に各注入材の環境 温度毎における初期粘度と表-6 で示した各試験ケース における到達距離から注入が停滞し始める時間を求めた 結果をそれぞれ示す. 環境温度 $5^{\circ} \mathrm{C}$ おび $0^{\circ} \mathrm{C}$ の初期粘 度と可使時間は, 注入材 $\mathrm{D}$ を除いて, 環境温度 $20^{\circ} \mathrm{C}$ の 值に対して $5^{\circ} \mathrm{C}$ で概ね 4 倍, $0^{\circ} \mathrm{C}$ で概ね 6 7 7倍に増加し ている，前述のように，エポキシ樹脂は温度を $10^{\circ} \mathrm{C}$ 上 昇させると硬化速度が 2 倍, 硬化時間は $1 / 2$ 倍となる ${ }^{18}$ とあり，本実験ではこれよりも若干大きな值となってい るが，低温での注入材の初期粘度と可使時間を求める目 安となると考える. これに低温の補正係数 $\alpha=5.60 \times 10^{4}$ を用いた注入面積速度から，現地のひび割れの状況に応
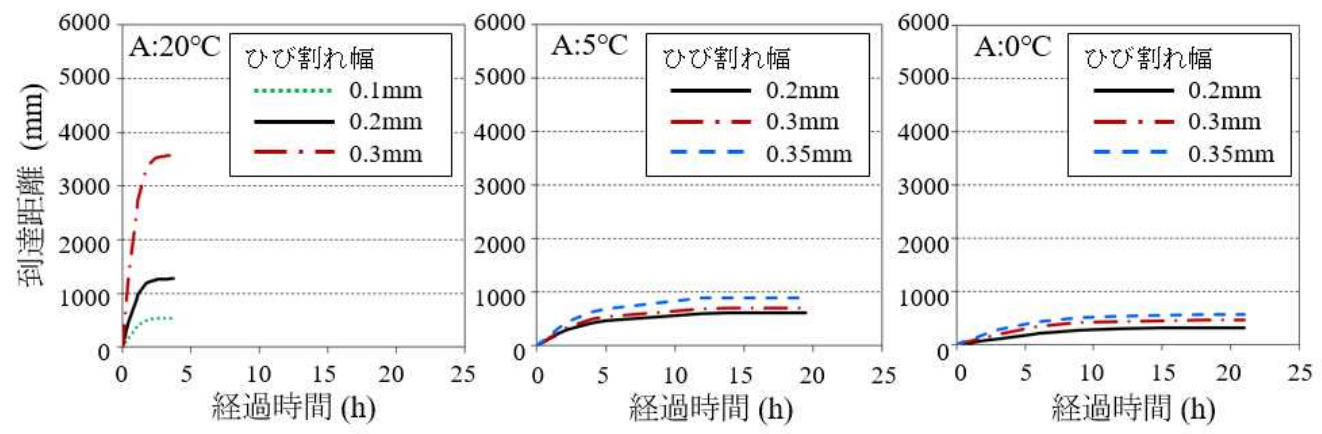

図-16 注入材 $\mathrm{A} の$ 経過時間と到達距離の関係（一例）

表-7 各注入材の環境温度毎の初期粘度と注入が停滞し始める時間

\begin{tabular}{|c|c|c|c|c|c|c|c|c|c|c|}
\hline 環境条件 & \multicolumn{2}{|c|}{$20^{\circ} \mathrm{C}$} & \multicolumn{4}{|c|}{$5^{\circ} \mathrm{C}$} & \multicolumn{4}{|c|}{$0^{\circ} \mathrm{C}$} \\
\hline 注入材 & $\begin{array}{l}\text { 初期粘度 } \\
(\mathrm{dPa} \cdot \mathrm{sec})\end{array}$ & $\begin{array}{l}\text { 注入停滞 } \\
\text { 時間(min) }\end{array}$ & $\begin{array}{l}\text { 初期粘度 } \\
(\mathrm{dPa} \cdot \mathrm{sec})\end{array}$ & $\begin{array}{l}20^{\circ} \mathrm{C} \text { と } \\
\text { の比率 }\end{array}$ & $\begin{array}{c}\text { 注入停滞時 } \\
\text { 間(min) }\end{array}$ & $\begin{array}{l}20^{\circ} \mathrm{C} \text { と } \\
\text { の比率 }\end{array}$ & $\begin{array}{l}\text { 初期粘度 } \\
(\mathrm{dPa} \cdot \mathrm{sec})\end{array}$ & $\begin{array}{l}20^{\circ} \mathrm{C} \text { と } \\
\text { の比率 }\end{array}$ & $\begin{array}{c}\text { 注入停滞時 } \\
\text { 間(min) }\end{array}$ & $\begin{array}{l}20^{\circ} \mathrm{C} \text { と } \\
\text { の比率 }\end{array}$ \\
\hline A & 6.5 & 143 & 30.6 & 4.7 & 540 & 3.8 & 50.1 & 7.7 & 1080 & 7.6 \\
\hline B & 6.8 & 240 & 28.98 & 4.3 & 960 & 4.0 & 48.5 & 7.1 & 1800 & 7.5 \\
\hline $\mathrm{C}$ & 2.0 & 17.1 & 8.5 & 4.3 & 65 & 3.8 & 12.0 & 6.0 & 120 & 7.0 \\
\hline D & 1.0 & 90 & 3.0 & 3.0 & 360 & 4.0 & 4.43 & 4.4 & 1080 & 12.0 \\
\hline
\end{tabular}


じた注入充塡性の評価を行うことが可能であると考える。

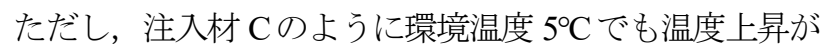
ある注入材は補正係数 $\alpha=5.60 \times 10^{4}$ に該当しないため, このような注入材を事前に判別するための確認試験は必 要である. その確認方法としては, 実際の低温の施工現 場における温度変化を JSCE-K 541-2013 の温度上昇法に 準じて測定して注入材の温度上昇の有無を調べる試験を 事前に行うことで解決できると思われる.

ここで，本害験の内，排出せずに途中で硬化した注入 材 $\mathrm{C}$ の環境温度 $0^{\circ} \mathrm{C}$, ひび割れ幅 $0.2 \mathrm{~mm}$ の試験ケース において，式(1)を用いて停滞した原因の検証を行った。 この試験ケースでは, 注入充填性試験の断面確認におい て, 注入材が供試体の半分程度（深さ $100 \mathrm{~mm}$ ) まで注 入材 C が充填されているのを確認している. しかし， 注入が途中で停滞して結果的に排出面から排出しなかっ たため, 注入が途中で停止するまでの注入時間は確認で きていない，そのため，実測值の注入面積速度は算定で きない，そこで，注入材 $\mathrm{C}$ のカタログ值から，初期粘 度を $1.5 \mathrm{dPa} ・ \sec$ を 6 ～倍した 9〜 $10.5 \mathrm{dPa} ・ \sec$ とし, また環境温度 $0^{\circ} \mathrm{C}$ で温度上昇がなかったため補正係数を $\alpha=5.60 \times 10^{4}$ として式(1)から注入面積速度を計算した。

この注入面積速度を供試体に注入される平均速度と仮定 し，カタログ值の可使時間 $14 \mathrm{~min}$ を 6〜7倍して 84〜98 min までの到達距離を計算すると到達距離はともに 87.75 $\mathrm{mm}$ となった. 実際には粘度が増加して注入面積速度は 徐々に遅くなり, 注入量 $30 \mathrm{~g}$ では可使時間がカタログ 值よりも少し長くなるため, この到達距離は妥当な計算 值であると考える，以上の結果から，本実験における結 果の範囲であるが，低温環境における注入材の注入充填 性を補正係数 $\alpha=5.60 \times 10^{4}$ を用いた注入面積速度の算定 式(1)により評価可能であることが示唆された。

\section{8. 結論}

本研究では，コンクリート構造物の補修工法であるひ び割れ注入工法において, 低温環境下における注入性能 や施工性，それに伴う注入後の充填性が不明確である工 ポキシ樹脂系ひび割れ注入材の注入充填性について, 既 往の研究で提案された注入面積速度によって定量的に評 価することを試みた。エポキシ樹脂系ひび割れ注入材は 一般に環境温度 $5^{\circ} \mathrm{C}$ 以上での施工が推奨されるが，実際 には環境温度 $5^{\circ} \mathrm{C}$ 以下での施工もしくはコンクリート内 部温度が $5^{\circ} \mathrm{C}$ 以下での施工が実施されているため， $5^{\circ} \mathrm{C}$ と $0^{\circ} \mathrm{C}$ における各種注入材の経時粘度と硬化反応による 温度変化を把握し，ひび割れを導入したコンクリート円 柱供試体への注入実験によって注入時間とひび割れ内の 注入材の充填率を求めた結果, 低温環境における注入充
塡性について，以下のような知見を得た。

1) 環境温度 $5^{\circ} \mathrm{C}$ では, 温度上昇法で可使時間を評価でき ない注入材が存在する.これらの注入材は低温では硬 化反応による発熱がほとんどない状態で硬化反応が進 行する. また, $30 \mathrm{~g}$ 程度の少量では温度上昇法で可使 時間を評価することができない．

2) 攪汼から硬化までのエポキシ樹脂系ひび割れ注入材は, 常温に比べて低温になるほど粘度が 4〜 7 倍程度大き くなり，硬化までの時間も増加するため，低温になる ほど注入効率は悪くなる.

3) 温度環境にかかわ和らず，注入面積速度が速いと排出口 付近の充填率は低下寸る傾向がある。これは注入面積 速度が速くなると注入材がひび割れ内で流下しやすく なる，もしくは流入しやすい空間（空隙）を通過して 拡散されないことが原因と考える.

4) 低温環境におけるエポキシ樹脂系ひび割れ注入材の注 入充填性について，低温においても注入面積速度とひ び割れ幅の関係に一定の相関が認められる.しかし， 注入材の発熱状態によって補正係数 $\alpha$ は異なると考え られる.ほとんど発熱しない環境では補正係数 $\alpha=$ $5.60 \times 10^{4}$ を提案する.

5) 本実験結果の範囲において，5ㄷ 以下の低温環境では ほぼ発熱しない注入材が多く, その場合, 補正係数 $\alpha$ $=5.60 \times 10^{4}$ を用いた注入面積速度の関係式(1)から注入 材の到達距離を予測することにより，低温時のひび割 れ幅やひび割れの規模に応じた注入材の選定や注入効 率を事前に把握することが可能であると考えられる. 本研究では，低温環境におけるエポキシ樹脂系ひび割 れ注入材の注入充垻性を注入面積速度である程度定量的 に評価できたことにより，ひび割れ注入工法の低温時の 問題点を解決する一助となる情報を得たことができたと 考える. 今後の課題として, 低温環境における注入材の 初期粘度の簡易測定方法等を含め, 規模の大きい供試体 もしくは実構造物による検証を行うための適用条件等を 検討していく必要がある.

謝辞 : 本実験を実施するにあたり，共同研究者である注 入材料メーカー各社の関係者に多大なるご協力を頂いた. ここに記して深甚な謝意を表します。

\section{参考文献}

1) 渡辺博志：コンクリート構造物の信頼性の向上一ひ び割れの影響一, 土木技術資料, 平成 24 年 1 月号, pp. 42-45, 2012.

2) 国立研究開発法人土木研究所 : コンクリート構造物 の補修対策施工マニュアル（案），土木研究所資料， 第 4343 号, 2017.

3) 日本コンクリート工学会 : コンクリートのひび割れ 調査, 補修・補強指針 2013, pp. 120-121, 2013. 
4) 内藤勲, 田口史雄, 島多昭典 : ひび割れ注入工法の 現状調查と凍結融解作用が注入後の耐久性に及ぼす 影響, コンクリート構造物の補修, 補強アップグレ ード論文報告集, 第 13 巻, pp. 517-522, 2013.

5) Naitoh, I., Shimata, A. and Mihara, N.: Study on the filling ability of crack injection into concrete in a cold snowy region, The $6^{\text {th }}$ International Conference of Asian Concrete Federation, USB stick, 2014.

6) 内藤勲, 島多昭典, 三原慎弘：施工時の低温環境が ひび割れ注入工法の注入充填性に及ぼす影響, コン クリート構造物の補修, 補強アップグレード論文報 告集, 第 14 巻, pp. 303-308, 2014.

7) 建設省：建設省総合技術開発プロジェクト，コンク リートの耐久性向上技術の開発，報告書，第二編， pp. 221-222, 1988.

8) 日本コンクリート工学会 : コンクリートのひび割れ 調查，補修・補強指針 2013，pp. 127-128, 2013.

9) 内藤勲, 田口史雄 : 小径コアによるひび割れ注入後 の充填評価方法に関する検討, 土木学会第 68 回年次 学術講演会, V-390, 2013.

10) 深町卓也, 原田耕司, 伊藤幸広 : 構造物検査用内視 鏡を用いたひび割れ注入管理技術の開発，コンクリ 一ト工学年次論文集, Vol. 33, No. 2, pp. 1519-1524, 2011.

11）山口岳思，鎌田敏郎，寺田孝，六郷恵哲：超音波に よるコンクリートひび割れ注入材の充填確認方法, コンクリート工学年次論文集, Vol. 27, No. 1, pp. 1681-1686, 2005.

12) 上村克郎, 小西敏正, 橘高義典 : 鉄筋コンクリート 造のひび割れ補修における樹脂の充填程度の数式化,
セメント技術年報 42, pp. 491-494, 1988.

13) 瀬野康弘, 魚本健人：ひび割れ注入補修における注 入時間と注入量の予測に関する基礎的研究, 土木学 会論文集 E, Vol. 64, No. 1, pp. 160-172, 2008.

14）西脇智哉，三橋博三，郡司幸弘：ひび割れへの補修 剂浸透に関する実験的検討, コンクリート工学年次 論文集，Vol. 30, No. 2, pp. 637-642, 2008.

15) 毛利聡, 大久保孝昭：可視化試験体を用いたひび割 れ補修材の注入性状の評価技術, 日本建築学会技術 報告集，第 21 巻，第 47 号, pp. 29-34, 2015.

16）建設省：建設省総合技術開発プロジェクト，コンク リートの耐久性向上技術の開発, 報告書, 第二編, p. 259, 1988.

17) 土木学会規準：JSCE-K-541-2013, コンクリート構造 物補修用有機系ひび割れ注入材の試験方法（案）, p. 436, 2013.

18）友井正男: 熱硬化性樹脂の基礎, エレクトロニクス 実装学会誌, Vol. 4, No. 6, pp. 537-542, 2001.

19) 国立研究開発法人土木研究所：コンクリート構造物 の補修対策施工マニュアル（案），土木研究所資料， 第 4343 号, p. IV-2, 2017.

20) 山本昌宏, 谷村成, 藤井隆史, 安藤尚, 綾野克紀 : 微細なひび割れを持つコンクリート試験体の作製方 法とそれを用いたひび割れ補修材の性能確認試験方 法に関する研究, コンクリート構造物の補修, 補強 アップグレード論文報告集，第 12 巻, pp. 467-472, 2012.

(Received March 23, 2020)

(Accepted September 7, 2020)

\section{EVALUATION ON PERFORMANCE OF EPOXY RESIN FOR CRACK INJECTION OF CONCRETE IN COLD ENVIRONMENT}

\section{Isao NAITO and Hiroshi YOKOTA}

To quantitatively evaluate the performance of epoxy resins for crack injection in cold environment, we performed injection tests using cylindrical specimens with controlled crack widths during which the changes in viscosity and temperature of the epoxy resins were measured during the injection. This paper presents the results of the areal rate into a crack under various temperatures and injection rates.

As a result, the injection performance of epoxy resins depends on the environmental temperature inside the crack because the resin changes its temperature very little due to its chemical reaction in low temperature environments. In addition, the injection areal rate has a correction with the environmental temperatures of $5^{\circ} \mathrm{C}$ or less. From this correlation, it is possible to quantitatively evaluate the injection performance of epoxy resin for crack injection in cold environment at the design stage. 